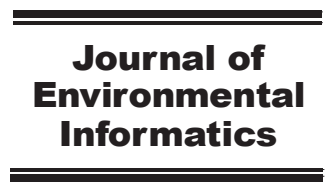

Www.iseis.org/jei

\title{
GIS-Based Reach File Generation for Efficient TMDLs Implementation
}

\author{
C. Lee ${ }^{1}$, K. Kim ${ }^{1, *}$, Y. Park ${ }^{1}$ and H. Lee ${ }^{2}$ \\ ${ }^{1}$ Department of Geoinformatics Engineering, Inha University, Incheon, 22212, Republic of Korea \\ ${ }^{2}$ Water Quality Control Center, National Institute of Environmental Research, Incheon, 22689, Republic of Korea
}

Received 23 June 2014; revised 1 January 2016; accepted 12 February 2016; published online 26 July 2016

\begin{abstract}
The ability to generate stream network data is essential to conducting fast searches and accurate analyses to obtain various types of environmental information on individual streams required to implement a Total Maximum Daily Loads (TMDLs) program. This study presents a major concept, an algorithm, and a procedure to build such stream network data, the Korean Reach File (KRF), based on a geographic information system (GIS). For the generation of the KRF's graphic data, a 1:25,000 scale nationwide river/stream map, a watershed map, and a polygon type administrative district map were utilized to delineate stream flow lines, split stream reaches, and assign unique identifiers. To generate the KRF's attribute data, we designed attribute tables for all the graphic data. All the attributes were inputted to each item of graphic data according to designed attribute input rules and the KRF was generated in a shapefile format. To evaluate the accuracy of the graphic data, we compared the stream lengths of the KRF on national level streams with actually surveyed stream lengths. The study results showed the graphic and attribute data that were generated for the four major river basins with a total stream length of 21,163 km. The Mean Absolute Percentage Error (MAPE) was about 3.8\%, and we confirmed that the KRF network data were generated with relatively high spatial accuracy. The KRF's applicability for the TMDLs was also discussed with exam-ples. In the future, a GIS-based management system using the KRF should be developed to support TMDLs more efficiently.
\end{abstract}

Keywords: geographic information system (GIS), Korean Reach File (KRF), Total Maximum Daily Loads (TMDLs), stream network analysis

\section{Introduction}

The Ministry of Environment (MOE) in South Korea has adopted and carried out a Total Maximum Daily Loads (TMDLs) program since 2002, and it has collected much pollution source data and water quality data nationwide to support the TDMLs (Kong, 2005). Then, to enable efficient management and sharing of collected data, many computerization studies regarding construction of databases and development of information systems have been pursued since 2003 (NIER, 2011). However, it was impossible to search and analyze water environment data spatially on the developed system; it only enabled users to ask for water pollution source data and water quality data with exact coordinates or unique identifier codes. In addition, stream network analysis that considered stream connectivity was not supported in the existing systems. Therefore, the necessity of a geographic information system (GIS) based data mining and analysis technology has been increasing.

GIS technology has already been used to find the causes of water pollution problems and predict the future water quality in many other environmental studies in the past (Karimi-

\footnotetext{
* Corresponding author. Tel.: +82 32 8754413; fax: +82 328631506 .

E-mail address: kyehyun@inha.ac.kr.
}

ISSN: 1726-2135 print/1684-8799 online

(C) 2016 ISEIS All rights reserved. doi:10.3808/jei.201600336 pour et al., 2005; Luk et al., 2004; Huang and Chang, 2003) because a GIS is effective in handling complicated spatial information that is essential for many environmental studies as well as in providing platforms for integrating various models, systems, and interfaces (Huang et al., 1999; Lovejoy et al., 1997). The United States Environmental Protection Agency (EPA) has utilized the GIS in implementation of TMDLs since the 1990s. In this process, it has developed spatial framework data such as the River Reach file (RF) to efficiently integrate and provide all the relevant data and information in a GIS environment.

The RF is a topographical database of surface water features; it defines the stream branch unit, which is a stream reach, and represents the topographical relationship between reaches (USEPA, 1994a, b). The RF consists of graphic data and attributes data. Graphic data were produced through the division of stream network into line type features and generalization of the stream into the units of the stream reach. And attribute data were generated by assigning unique identifiers to individual stream reaches and linking various attributes of relevant watershed sections. Recently, the RF has been included in the National Hydrography Dataset (NHD), which has been developed for integrated management of spatial data on surface water for more diverse use.

The RF has been utilized for GIS-based management of water environment information in the TMDLs studies (Cooter et al., 2010; Ries et al., 2010). The spatial data representing 
Table 1. Characteristics of Four Major River Basins in South Korea

\begin{tabular}{|c|c|c|c|c|c|c|c|c|c|}
\hline $\begin{array}{l}\text { Basin } \\
\text { division }\end{array}$ & $\begin{array}{l}\text { Main river } \\
\text { name }\end{array}$ & $\begin{array}{l}\text { Drainage } \\
\text { area } A_{W} \\
{\left[\mathrm{~km}^{2}\right]}\end{array}$ & $\begin{array}{l}\text { Basin } \\
\text { perimeter } \\
\mathrm{L}_{\mathrm{p}}[\mathrm{km}]\end{array}$ & $\begin{array}{l}\text { Basin } \\
\text { river } \\
\text { length } \\
\mathrm{L}_{\mathrm{b}}[\mathrm{km}]\end{array}$ & $\begin{array}{l}\text { Effective } \\
\text { basin width } \\
\mathrm{R}_{\mathrm{b}}\left(=\mathrm{A}_{\mathrm{w}} / \mathrm{L}_{\mathrm{b}}\right) \\
{[\mathrm{km}]}\end{array}$ & $\begin{array}{l}\text { Form } \\
\text { factor } \\
\mathrm{R}_{\mathrm{f}}(= \\
\left.\mathrm{A}_{\mathrm{w}} / \mathrm{L}_{\mathrm{b}}^{2}\right)[-]\end{array}$ & $\begin{array}{l}\text { Major } \\
\text { city }\end{array}$ & $\begin{array}{l}\text { Population } \\
\text { number in city } \\
\text { [Thousand } \\
\text { People] }\end{array}$ & $\begin{array}{l}\text { Population } \\
\text { density in } \\
\text { city [People/ } \\
\mathrm{km}^{2} \text { ] }\end{array}$ \\
\hline \multirow{2}{*}{$\begin{array}{l}\text { Han River } \\
\text { Basin }\end{array}$} & \multirow[t]{2}{*}{ Han River } & \multirow[t]{2}{*}{23,293} & \multirow[t]{2}{*}{1,124} & \multirow[t]{2}{*}{494} & \multirow[t]{2}{*}{47} & \multirow[t]{2}{*}{0.10} & Seoul & 10,026 & 16,567 \\
\hline & & & & & & & Incheon & 2,750 & 2,664 \\
\hline \multirow{2}{*}{$\begin{array}{l}\text { Nakdong } \\
\text { River } \\
\text { Basin }\end{array}$} & \multirow{2}{*}{$\begin{array}{l}\text { Nakdong } \\
\text { River }\end{array}$} & \multirow[t]{2}{*}{23,702} & \multirow[t]{2}{*}{1,097} & \multirow[t]{2}{*}{512} & \multirow[t]{2}{*}{46} & \multirow[t]{2}{*}{0.09} & Busan & 3,464 & 4,509 \\
\hline & & & & & & & Daegu & 2,477 & 2,803 \\
\hline $\begin{array}{l}\text { Geum } \\
\text { River } \\
\text { Basin }\end{array}$ & $\begin{array}{l}\text { Geum } \\
\text { River }\end{array}$ & 9,914 & 738 & 389 & 25 & 0.07 & Daejeon & 1,527 & 2,827 \\
\hline $\begin{array}{l}\text { Yeongsan/ } \\
\text { Seomjin }\end{array}$ & $\begin{array}{l}\text { Yeongsan } \\
\text { River }\end{array}$ & 3,470 & 435 & 135 & 26 & 0.19 & Gwangju & 1,506 & 3,005 \\
\hline $\begin{array}{l}\text { River } \\
\text { Basin }\end{array}$ & $\begin{array}{l}\text { Seomjin } \\
\text { River }\end{array}$ & 4,914 & 671 & 223 & 22 & 0.10 & - & - & - \\
\hline
\end{tabular}

Table 2. List of Collected Spatial Data

\begin{tabular}{lllllll}
\hline Spatial data name & Type & Format & $\begin{array}{l}\text { Feature } \\
\text { class }\end{array}$ & Scale & Year & Custodian \\
\hline River/stream map & Vector & Shapefile & Polygon & $1: 25 \mathrm{~K}$ & 2005 & $\begin{array}{l}\text { Ministry of Environment } \\
\text { (MOE) }\end{array}$ \\
& Vector & Shapefile & Point & $1: 25 \mathrm{~K}$ & 2009 & MOE \\
$\begin{array}{l}\text { Dam location map } \\
\text { Weir location map }\end{array}$ & Vector & Shapefile & Point & $1: 25 \mathrm{~K}$ & 2009 & MOE \\
$\begin{array}{l}\text { Administrative district boundary } \\
\text { map }\end{array}$ & Vector & Shapefile & Polygon & $1: 5 \mathrm{~K}$ & 2009 & MOE \\
$\begin{array}{l}\text { Standard watershed boundary map } \\
\text { Sector }\end{array}$ & Shapefile & Polygon & $1: 25 \mathrm{~K}$ & 2002 & MOE \\
\hline
\end{tabular}

the stream flows have been used in connection with various measurement data and watershed data. The Watershed Assessment, Tracking \& Environment Results (WATERS) is one of the representative systems for managing and providing water environment information (USEPA, 2013a). Furthermore, it has been used for modeling of water quality prediction such as Better Assessment Science Integrating point and Non-point Sources (BASINS), SPAtially Referenced Regressions On Watershed attributes (SPARROW) and RiverSpill model (USEPA, 2001,2013b; Ierardi et al., 2004; Dewald and Roth, 1997).

However, in South Korea, there were no similar stream network data to support the TMDLs program implementation. Therefore, it must be produced before South Korea develops relevant GIS-based information systems as in the U.S. However, following the U.S. example without considering the conditions of South Korea presented difficulties. There was no stream network map available to be used as reference material in South Korea. In addition, it was not possible to use the GISbased stream network data extraction method using Digital Elevation Model (DEM) data because most rivers and streams are relatively narrow and short. Thus, stream network data should be produced with a new approach and examined through empirical research.
The aim of this study was to generate the GIS-based stream network data, the Korean Reach File (KRF), to support the TMDLs program implementation. To build the KRF's graphic data, we proposed a generation method based on previous studies (Kwon et al., 2012; Lee et al., 2013). A stream line map was generated to represent the stream flows. Then, individual stream reaches were defined and delineated using the stream line map. In determining the stream reaches, point-type graphic data were created at the start and end points of each stream reach. As a major reference to build the KRF, we reviewed the U.S. EPA's Reach File version 3 (RF3) (USEPA, 2003a, b; Lee, 2005). The accuracy of the KRF's graphic data was proven to be acceptable. Finally, we discussed the applicability of the KRF to facilitate the Korean TMDLs.

\section{Study Area and Spatial Data Collection}

\subsection{Study Area}

The target area of this study was the four major river basins in South Korea consisting of Han River, Nakdong River, Geum River, and Yeongsan/Seomjin River. Table 1 shows the features of each basin, and Figure 1 shows the distribution of streams of each basin and the boundaries of the four major river 


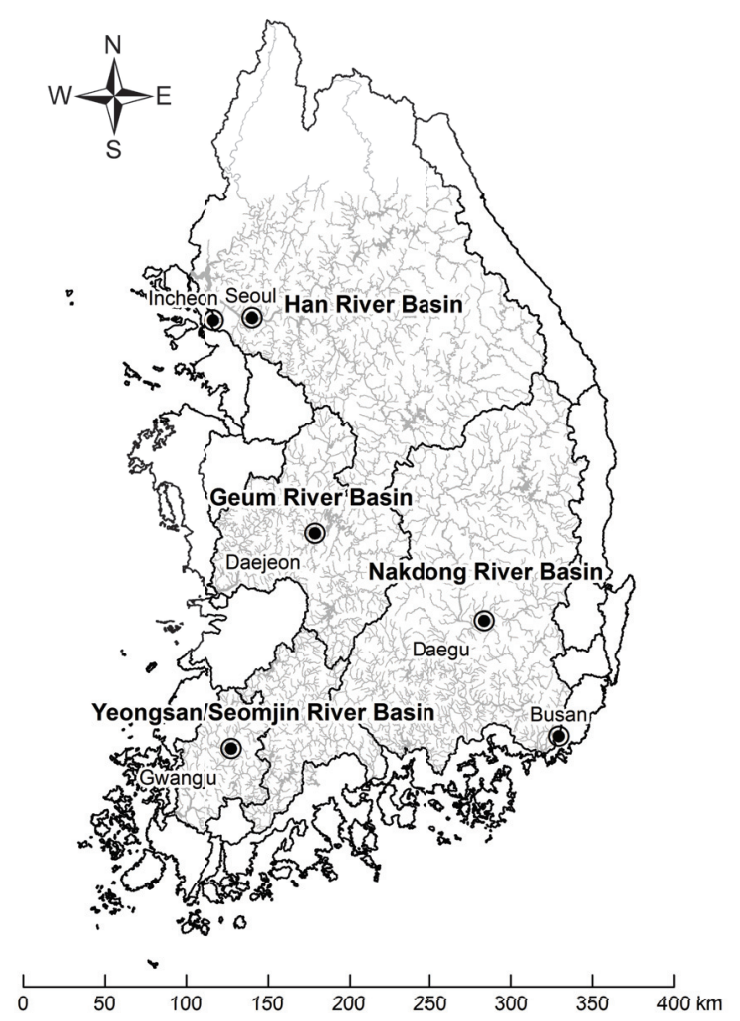

Figure 1. Study area: four major river basins and river streams in South Korea.

basins. The total size of the four river basins is about 65,293 $\mathrm{km}^{2}$ which is $64.5 \%$ of the national territory (MLTM, 2013). They include major metropolitan areas that contain more than $60 \%$ of the total population of the nation. Considering the recent deterioration of water quality and higher demands to mitigate water pollution, the four river basins are appropriate for this study.

\subsection{Collection of Spatial Data}

Spatial data related to the generation of the KRF were collected with the cooperation of the MOE. Table 2 shows the list of collected spatial data for this study. The river/stream map in a vector format that represents the stream's left and right boundaries was obtained as required for drawing a stream flow line map. That data was in a shapefile format including polygon type data with a scale of 1:25,000 and was normally utilized by the MOE for TMDLs studies. In addition, point type shapefiles showing the location of dams and weirs as well as polygon type shapefiles showing the administrative district boundaries and basin boundaries were collected from the MOE to split stream reaches and generate relevant attributes.

\section{Generation of KRF's Graphic Data}

\subsection{Definition of Graphic Data}

The generation of a dataset based on a network data model is required to carry out GIS based network analysis. The widely used network data model 'arc-node model' (Kim, 2010) was adopted. This model structurally stores the information on the relationship of collection and connection of the line and point type data. This also enables definition of network directionality and the identification of upper and lower streams (Maidment, 2002; Kim et al., 2004a, b; Kim, 2010). This was considered as suitable to generate the KRF's graphic data based on the arc-node model since the KRF should also support stream network analysis. The line type data were generated by delineating the stream flow lines from the river/stream map and splitting them into the units of the stream reaches. Finally, the point type data were generated through screen digitizing of inlet and outlet points of each stream reach.

\subsection{Generation Method of Graphic Data}

In preceding studies, a Digital Elevation Model(DEM) was generally used in the delineation of stream flow lines. Stream flow lines for specific basins were delineated through assigning appropriate threshold values depending on the experience of the expert analysts (Maidment, 2002; Maidment and Djokic, 2000; Saunders, 1999; Tarboton et al., 1991; Jensen and Domingue, 1988). However, this method could generate network data for sections where actual streams do not exist or, on the other hand, network data might not be created in a section where a stream actually exists. This implies that the network data generated using the DEM can have more or fewer stream branch points than actually exist, thus leading to distortion of the network shape compared to the actual stream as well as distortions of the stream length. This shortfall of DEM could undermine the accuracy of the network analysis.

In this perspective, the stream flow lines represented by the line type feature of the KRF were delineated using 'the skeletonizing method for the vector data' proposed by Lee et al. $(2009,2013)$ and Park et al. (2010). The skeletonizing method for the vector data extracts the center points of each stream and connects them. It extracts all the vertices on the stream boundary line then extracts the center points of the maximum inscribed circle adjoining them. The center points of the maximum inscribed circle extracted are considered as the vertices of the stream flow line and the stream flow lines are created by connecting them. The center points and connection lines created unnecessarily in the process of flow line drawing were removed through visual inspection at post-processing phase. In particular, if a loop occurs due to the islands in the stream, then any extraneous lines were deleted so that only one flow exists in one stream.

Upon completing the flow line delineation, each stream flow line was divided into the unit of stream reach. The stream reach was defined to represent the stream section divided by the 'location of the stream confluence', 'location of the stream water source and drainage points', 'location of dams and weirs', and 'location of stream boundary points on a vector type stream map'. The 'location of the stream confluence' was defined as the location of the points where the stream joins a branch as it flows down from the upper stream water source of all streams according to the stream flow direction. The 'location of the 


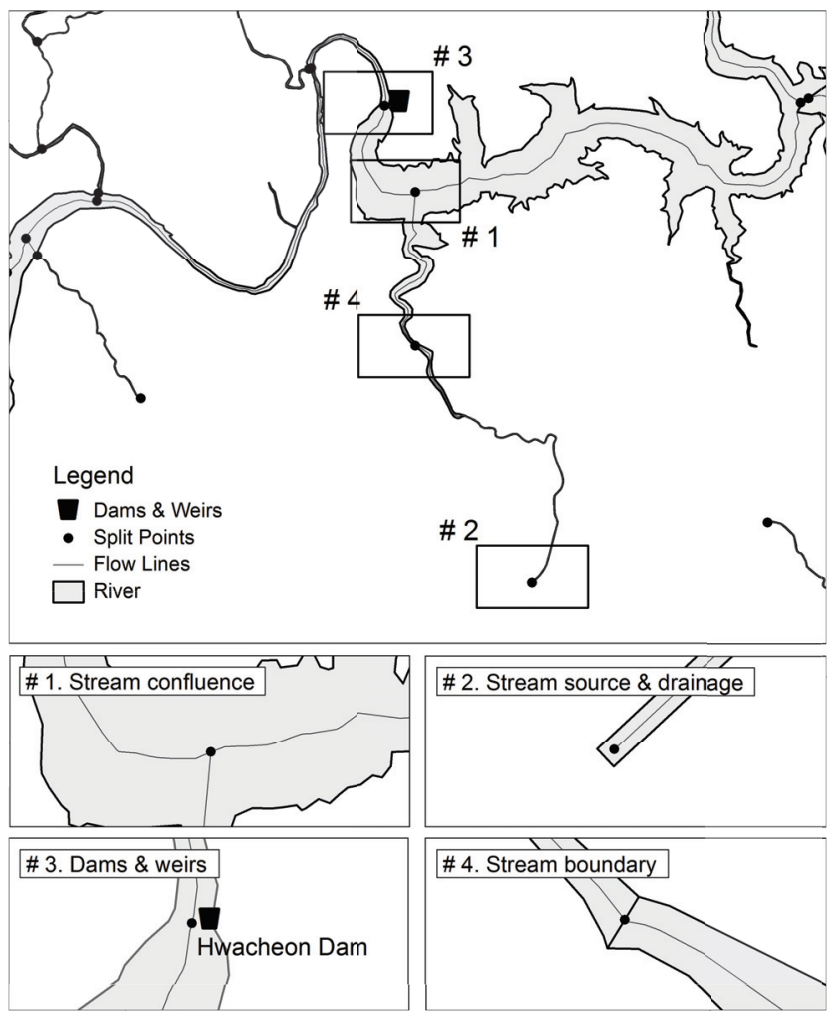

Figure 2. Example of split flow lines.

stream water source and drainage points' was defined as the uppermost water source point and the lowermost water drainage point of each stream. The 'location of dams and weirs' was defined as the location of a point where it exists on the stream flow line most closely after overlaying with the point type graphic data showing the location of existing dams and weirs. The 'location of the stream boundary point on a vector type river/stream map' was defined as the location where the delineated stream flow line and stream boundary cross each other. Figure 2 shows the four examples mentioned above.

Since these split standards clarify the split location of a stream reach, it is possible to obtain results with a certain degree of accuracy at a predictable level of error even if graphic data are generated by numerous different researchers. In addition, it is advantageous for clarifying the definition of the topological relationship since it enables the clarification of the connectivity, inclusion and neighborhood relationship between points (inflow and outflow points of each stream reach), lines (stream flow line) and polygons (river/stream map). It is also advantageous in terms of generation and inspection of graphic data since the split point can be easily checked through visual inspection. The stream flow lines split in the unit of stream reach were stored as line type graphic data of the KRF, and split points were stored as the point type graphic data of the KRF through screen digitizing with visual inspection.

\subsection{Assignment of the Unique Identifier}

Upon completing delineation of the graphical data of the stream network, it is necessary to assign a unique identifier for each graphic feature of the KRF. This unique identifier should be defined by the specific rules and should be generated for individual objects without duplication. The unique identifier should explain the main attributes of each object so that it can be used as the search key for relational joins to other programs or databases similar to the EPA's RF. The unique identifier of the EPA's RF consists of the Hydrologic Cataloging Units (CU) number, a Segment (SEG) number and a Marker Index (MI) number (USEPA, 1994a,b).

Rivers and streams in South Korea are separated and defined comprehensively considering humane, social, administrative and historical factors, along with hydrological factors. Each stream is assigned a unique code based on the Water Management Information Standard enacted by the government for effective information management regarding rivers and streams (MOCT, 2004). The various items of stream environment information are also stored in a database based on the 'standard stream code'. Accordingly, it was considered that this standard should also be reflected in the KRF for the utilization of database information in connection with the KRF.

Figure 3 shows the composition of the standard stream code adopted in South Korea. The standard stream code consists of a 2-digit basin number, a 1-digit stream level classification code for identifying management agencies ( 0 : national government, 1: local government level 1, 2: local government level 2), and a 4-digit sequential unique number assigned to each stream based on the confluence of the basin which is sequentially allocated in downstream order. The basin number of the standard stream code corresponds to the CU of the EPA's RF and the sequential unique number to the SEG of the EPA's RF, respectively. Additionally, this stream code can be used as the unique identifier by simply adding MI value at the end of the standard stream code.

The MI of the KRF was defined as the percentage value of the accumulated distance from the lowermost downstream to the split point to the total length of the specific stream based on the standard stream code. Equation (1) is the formula to calculate the $M I_{n}$ value of the $n^{\text {th }}$ stream reach $R_{n}$ included in the stream with the length of $S_{l}$. Figure 4 shows an example of the calculated MI values. The MI value of the uppermost stream reach is defined as 99.99999:

$$
M I_{n}=\left(\sum_{i=1}^{n} R_{i}-R_{n}\right) / S_{l} \times 100(\%)
$$

In this method, the stream flow lines are delineated from the polygon type river/stream map and split on the stream boundary according to the fourth split rule. This is different from the conventional method to delineate stream flow lines using DEM. Therefore, the stream reaches can be additionally generated in the connection area of the 'main stream to a tributary stream' in the KRF. However, such stream reaches additionally generated cannot be assigned a unique identified code with the combination of standard stream code and MI. This is due to the fact that the stream reach of a "main stream to a main 
Table 3. Attribute List of Point Type and Line Type Data for the KRF

\begin{tabular}{|c|c|c|}
\hline Class & Attributes of point type data & Attributes of line type data \\
\hline $\begin{array}{l}\text { Theme } \\
\text { attributes }\end{array}$ & $\begin{array}{l}\text { Feature ID, Catalog Units (CU), } \\
\text { Segments (SEG), Marker Index (MI), } \\
\text { Reach's node ID }\end{array}$ & $\begin{array}{l}\text { Feature ID, CU, SEG, MI, Upstream reach's MI, Tributary(TRIB), } \\
\text { Classification of main and tributary stream, Basin's name, River's name, Classi- } \\
\text { fication of main and tributary stream as river's name, Reach's line ID, River's } \\
\text { length, Reach's length/cumulative length, Presence of connected reach, Pres- } \\
\text { ence of start/end reach, (Reach's) Type/Level, Updated date }\end{array}$ \\
\hline $\begin{array}{l}\text { Location } \\
\text { attributes }\end{array}$ & Coordinates of X \& Y & (Inflow/Outflow, Max./Min.) Coordinates of X \& Y \\
\hline $\begin{array}{l}\text { Topology } \\
\text { attributes }\end{array}$ & $\begin{array}{l}\text { Number of connected reaches, Con- } \\
\text { nected downstream reach's ID, Name } \\
\text { of TMDL's watershed, Standard wa- } \\
\text { tershed's code, Administrative dis- } \\
\text { trict's code }\end{array}$ & $\begin{array}{l}\text { Administrative district's code, Inflow direction of main upstream, Inflow direc- } \\
\text { tion of complement reach, Presence of divergent reach, (Inflow/Outflow) Name } \\
\text { of TMDL's watershed/Standard watershed's code/Administrative district's } \\
\text { code/Reach's node ID, (Upstream left/Upstream right/Complement/ Down- } \\
\text { stream/Divergence) Reach's ID }\end{array}$ \\
\hline
\end{tabular}

\section{Level (national/local, 1)}

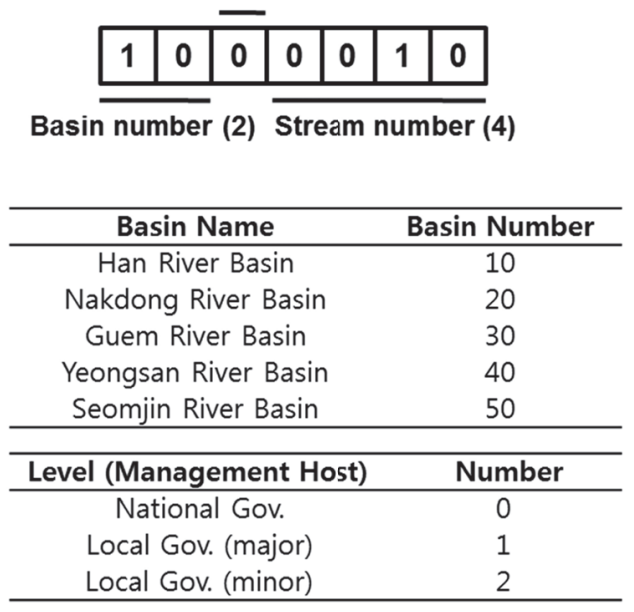

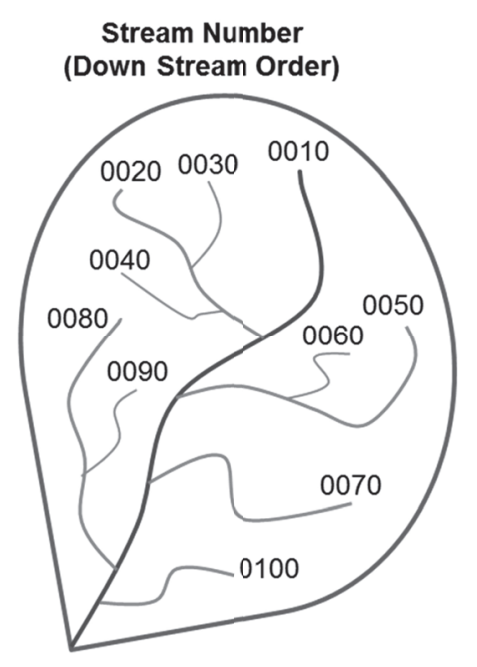

Figure 3. Composition of the standard stream code in South Korea.

stream' and the stream reach of a 'main stream to a tributary stream' can share one MI value at the confluence point, so that the same unique identifiers are to be assigned to such reaches. Figure 5a shows the problem of the unique identifier at the confluence point sharing the same MI value. In this figure, stream reach (A) of 'a main stream to a main stream' and stream reach (B) of 'a main stream to a tributary stream' are found to have the same identifier of '1002710 38.13853'.

Therefore, a 1-digit tributary (TRIB) code to identify the order of the tributary was added to the unique identifier of the line type graphic data to solve the problem of the duplicated unique identifier. The unique identifier of the point type graphic data was defined as the combination of the 7-digit standard stream code and 8-digit MI value while the unique identifier of the line type graphic data was defined by adding the TRIB code. Figure 5b shows an example of an assigned unique identifier to each stream reach. The numeric ' 1 ' is assigned for the main stream reach to represent the main stream flow while ' 2 ' for the connection stream reach of the 'main stream to a tributary stream, respectively. Figure 6 shows the composition of the unique identifier assigned to point type data and line type data in the KRF.

\section{Generation of KRF's Attribute Data}

\subsection{Consideration of EPA's RF Attribute}

To define the attributes of the KRF, the attributes of the EPA's RF have been reviewed. The EPA's RF attributes have been changed continuously during the development period

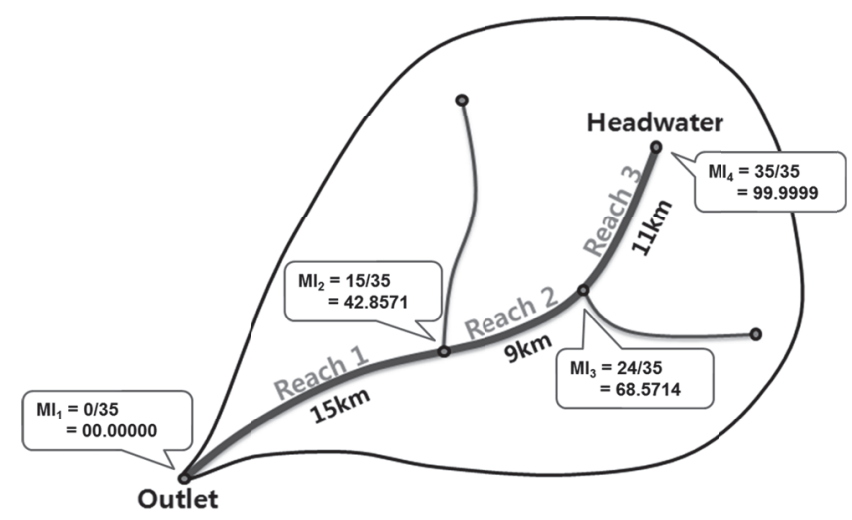

Figure 4. Example of calculated Marker Index values. 
over 30 years. Accordingly, the topological information has been updated to enhance the spatial search and analysis use in the RF3. The detailed attributes for hydrographical and water quality features on specific stream reaches were stored in a separate database and utilized for the users. This approach minimized the amount of attribute information to be stored with graphic data and reduced the processing speed required for the GIS analysis.

The attributes in the RF3's version have been adopted for the KRF attribute design considering that various databases of hydrology and water quality information have already been built by individual agencies. It was more effective to connect and utilize the RF3's attributes rather than to build new databases for the KRF. In addition, it seemed to be advantageous to store the minimum attribute data with graphic data to enhance the operational performance for the application purposes.

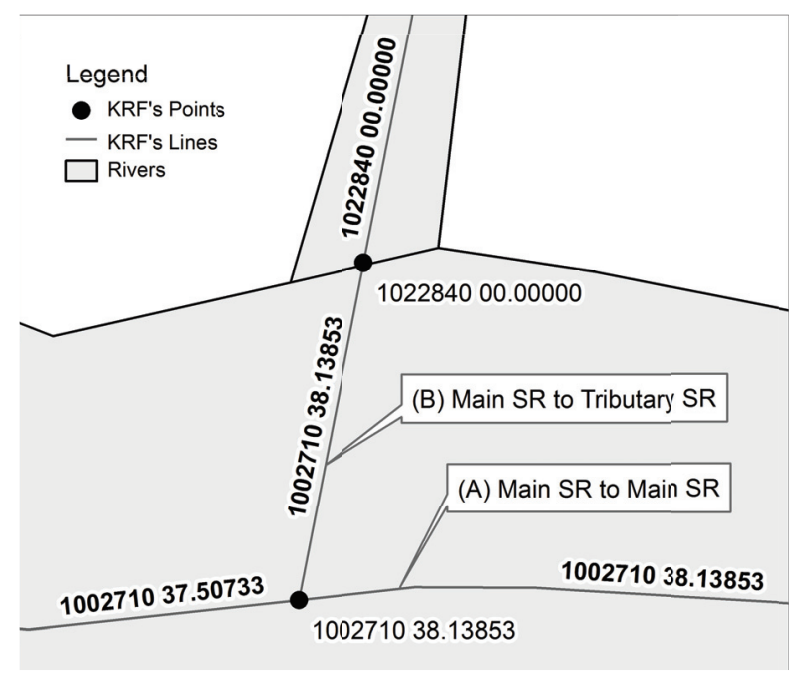

(a) Sharing of MI values at the stream confluence

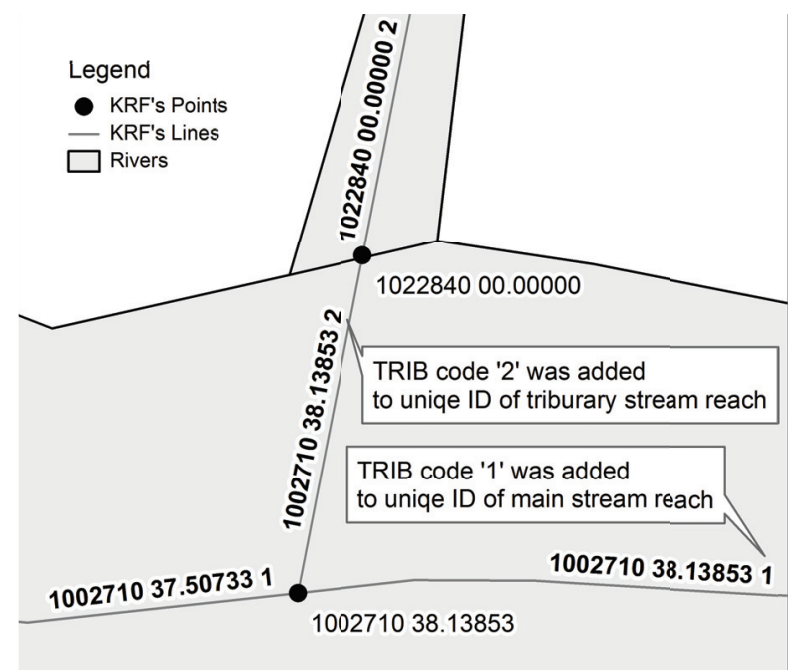

(b) Example of assigned unique ID for each graphic feature

Figure 5. Assignment of unique identifier for KRF's graphic features.

\subsection{Analysis of Korean TMDLs Works}

To define the detailed attributes for the KRF application, the Korean TMDLs work was analyzed. The TMDLs work guide and configuration details of MOE's database were reviewed. The pollution source and pollutant loading data have been managed by the administrative district units of each major watershed through MOE's database. In most database tables, the 'basin name', 'basin code', '(legally defined) administrative district name' and '(legally defined) administrative district code' were used in the database. They were also used for information searches and queries. In this regard, to take into account the connectivity and compatibility with TMDLs, the 'basin name', 'basin code', 'administrative district name' and 'administrative district code' were included in the KRF attributes.

\subsection{Attribute Modeling}

Attribute modeling was carried out in three categories: 'theme attributes,' 'location attributes' and 'topology attributes'. The theme attributes were modeled to contain the minimum amount of the thematic information in attributes so that stream environment data related to TMDLs could be efficiently managed using network data. In particular, the attributes such as 'stream name', 'stream code', 'basin name' and 'administrative district name' were included because they play key roles in relational joins with related databases. For the location attributes, 2-dimensional XY coordinates of the TM coordinate system were included in the attributes for the easier identification of the location of each feature object and fast search of the location. In addition, the minimum and maximum values of the XY coordinates were included in the attributes so that the Minimum Enclosing Rectangle (MER) method (Kim, 2010) could be applied for more efficient spatial indexing and searching. The topology attributes were modeled in reference to the EPA's RF3 attributes. They can be used for upstream and downstream navigation, the calculation of accumulated stream length, and the extraction of target stream reaches. Table 3 summarizes the details of the attributes defined through the attribute modeling process.

\subsection{Attribute Design and Input}

The field name, data type, length and definition of the KRF attributes were defined in the attribute table through a logical design process. Tables 4 and 5 show the results of attribute design of the KRF's point type and line type data. Attributes for all the graphic data were generated using ArcGIS Desktop 9.3.1 based on the attribute design. The location and topology attributes, which can be generated using the 'Calculate Field Geometry' and 'Identify' function, were automatically generated. In addition, the 'Spatial Join' and 'Overlay' functions were used to automatically input the theme attributes. Some attributes that could not be generated automatically were manually generated using the 'Editor' function.

\section{Results and Discussion}

\subsection{Result of Graphic Data Generation}

Figure 7 shows the generated results of the KRF's graphic 
Table 4. Specifications of the Attribute Table for Point Type Data

\begin{tabular}{|c|c|c|c|c|c|}
\hline No & Attribute & Field name & Type & Length & Definition \\
\hline 1 & Feature ID & FID & CHAR & various & The serial number of features \\
\hline 2 & Geometry & SHAPE & GM & various & The geometric information of reach's node \\
\hline 3 & Catalog units & $\mathrm{CU}$ & CHAR & 2 & 2-digits sub-basin code defined by K-WATER (ex.10) \\
\hline 4 & Segments & SEG & CHAR & 7 & 7-digits standard river/stream code (ex.100010) \\
\hline 5 & Marker index & MI & CHAR & 8 & $\begin{array}{l}\text { The ratio of the cumulative length from the outlet point of segment to the } \\
\text { node point in each segment (ex.00.0000) }\end{array}$ \\
\hline 6 & Reach's node ID & RCHNODEID & CHAR & 16 & The unique ID for reach's node with combination of SEG \& MI \\
\hline 7 & $\begin{array}{l}\text { Number of con- } \\
\text { nected reaches }\end{array}$ & NUM_RCH & NUM & 1 & The number of connected reaches at reach's node \\
\hline 8 & $\begin{array}{l}\text { Connected down- } \\
\text { stream reach ID }\end{array}$ & D_RCHID & CHAR & 18 & The connected downstream reach's line ID with reach's node \\
\hline 9 & $\mathrm{X}$-coordinate & TM_X & NUM & 10.3 & The X-coordinate of reach's node (Bessel/TM) \\
\hline 10 & Y-coordinate & TM_Y & NUM & 10.3 & The Y-coordinate of reach's node (Bessel/TM) \\
\hline 11 & $\begin{array}{l}\text { TMDL watershed } \\
\text { name }\end{array}$ & T_UW_NM & CHAR & 30 & The name of TMDL's watershed containing reach's node \\
\hline 12 & $\begin{array}{l}\text { Standard water- } \\
\text { shed code }\end{array}$ & K_SW_CD & CHAR & 6 & The code of standard watershed containing reach's node \\
\hline 13 & $\begin{array}{l}\text { Administrative } \\
\text { district code }\end{array}$ & ADM_CD & CHAR & 10 & The administrative district's code (according to legal standard) \\
\hline
\end{tabular}

\begin{tabular}{|c|c|c|c|c|c|c|c|c|c|c|c|c|c|c|c|c|}
\hline \multirow{3}{*}{$\begin{array}{c}\text { KRF's Point Data } \\
\text { Unique ID } \\
\text { (16 digit-code) }\end{array}$} & \multicolumn{15}{|c|}{ Level (national/local, 1) } & \\
\hline & 1 & 0 & 0 & 0 & 0 & 1 & 0 & 5 & 3 & . & 6 & 6 & 6 & 1 & 7 & \\
\hline & \multicolumn{3}{|c|}{ Basin number (2) } & Stre & eam & hum & ber $(4$ & \multicolumn{8}{|c|}{ MI (8) } & \\
\hline $\begin{array}{c}\text { KRF's Line Data } \\
\text { Unique ID }\end{array}$ & 1 & 0 & 0 & 0 & 0 & 1 & 0 & 5 & 3 & . & 6 & 6 & 6 & 1 & 7 & 0 \\
\hline
\end{tabular}

Figure 6. Composition of KRF's unique identifier.

data. A total of 7,047 stream reaches were created for a total of 2,402 streams using the standard stream code, and their total length was approximately 21,163 km. Among them, the number of stream reaches representing the pure flow line except the connection stream reach, which is the "main stream to the tributary stream' created by splitting on the stream boundary, was a total of 4,762 and their total length was $20,570 \mathrm{~km}$. The point type data were generated with the combination of a total of 7,052 nodes. Considering that the whole streams flow into to the sea at five locations (Han River, Nakdong River, Geum River, Youngsan River and Seomjin River), the total number of nodes should be more than the total number of stream reaches by five, and the result satisfied this. This confirms that the point type and line type data of the network dataset generated by the arc-node model were suitable.

\subsection{Result of Accuracy Evaluation on Graphic Data}

Table 6 shows the comparison result of the stream length from the KRF graphic data and the Korean River List for the major national streams. The Korean River List is the report that summarizes the actual field measurement data of the stream lengths periodically to establish the basic plans of river maintenance by the Ministry of Land, Transport and Maritime Affairs (MLTM) in South Korea. This study regarded the stream lengths from the Korean River List (MLTM, 2008) as the true values and the accuracy of the graphic data was evaluated by comparing the stream length from the KRF with that of the Korean River List.

The comparison was made for a total of 39 major national rivers and streams. As summarized in Table 6, there was no significant difference between the stream length of the Korean River List (A) and the stream length of the KRF (B). While some stream sections had a higher variation in stream length, we considered the magnitude of the difference not to be significant based on the result of the difference ratio to stream length (|A - B $\mid / A)$. The Mean Absolute Percentage Error (MAPE) for the target streams was about $3.8 \%$ and it was verified that accurate graphic data were generated. Additionally, from the scatter plot of Figure 8 showing the trend of the stream length difference, most of the stream lengths generally coincided with the actual surveyed values. Figure 8 also shows that all the streams were clustered closely along a straight line, suggesting that accurate graphic data were generated regardless of the 
Table 5. Specifications of the Attribute Table for Line Type Data

\begin{tabular}{|c|c|c|c|c|c|}
\hline No & Attribute & Field name & Type & Length & Definition \\
\hline 1 & Feature ID & FID & CHAR & various & The serial number of features \\
\hline 2 & Geometry & SHAPE & GM & various & The geometric information of reach's line \\
\hline 3 & Catalog units & $\mathrm{CU}$ & CHAR & 2 & 2-digits sub-basin code defined by K-WATER (ex.10) \\
\hline 4 & Segments & SEG & CHAR & 7 & 7-digits standard river/stream code (ex.100010) \\
\hline 5 & Marker index & MI & CHAR & 8 & $\begin{array}{l}\text { The ratio of the cumulative length from the outlet point of segment to } \\
\text { the end node point of reach in each segment (ex.00.0000) }\end{array}$ \\
\hline 6 & Upper marker index & UPMI & CHAR & 8 & $\begin{array}{l}\text { The ratio of the cumulative length from the outlet point of segment to } \\
\text { the start node point of reach in each segment (ex.99.99999) }\end{array}$ \\
\hline 7 & Tributary class & TRIB & CHAR & 1 & The geometric classification of main and tributary stream \\
\hline 8 & Basin name & BASIN_NM & CHAR & 30 & The name of basin containing reach \\
\hline 9 & Stream name & STR_NM & CHAR & 30 & The name of river/stream containing reach \\
\hline 10 & $\begin{array}{l}\text { Tributary class by } \\
\text { stream name }\end{array}$ & STR_NMTRIB & CHAR & 1 & The classification of main and tributary stream by stream's name \\
\hline 11 & Reach line ID & RCHLINEID & CHAR & 18 & The unique ID for reach's line with combination of SEG, MI \& TRIB \\
\hline 12 & Segment length & SEG_LEN & NUM & 10.3 & The length of river/stream of each segment \\
\hline 13 & Reach length & RCH_LEN & NUM & 8.3 & The length of instant reach \\
\hline 14 & Cumulative length & CUM_LEN & NUM & 10.3 & $\begin{array}{l}\text { The cumulative length from the outlet point of segment to the end } \\
\text { node point of reach in each segment }\end{array}$ \\
\hline 15 & $\begin{array}{l}\text { Reach connectivity } \\
\text { flag }\end{array}$ & R_FLAG & CHAR & 1 & The flag of reach's connectivity with downstream \\
\hline 16 & Terminal reach flag & T_FLAG & CHAR & 1 & The flag of terminal reach \\
\hline 17 & Start reach flag & S_FLAG & CHAR & 1 & The flag of start reach \\
\hline 18 & Reach type & RCH_TYPE & CHAR & 1 & The type of reach \\
\hline 19 & Level & LEV & CHAR & 1 & The level of river/stream defined by government \\
\hline 20 & $\begin{array}{l}\text { Administrative district } \\
\text { code }\end{array}$ & ADM_CD & CHAR & 10 & The administrative district's code (according to legal standard) \\
\hline 21 & $\begin{array}{l}\text { Upstream inflow direc- } \\
\text { tion }\end{array}$ & USDIR & CHAR & 1 & The inflow direction of main upstream \\
\hline 22 & $\begin{array}{l}\text { Upstream left reach } \\
\text { SEG }\end{array}$ & ULSEG & CHAR & 7 & The upstream left reach's SEG \\
\hline 23 & Upstream left reach MI & ULMI & CHAR & 8 & The upstream left reach's MI \\
\hline 24 & $\begin{array}{l}\text { Upstream left reach } \\
\text { TRIB }\end{array}$ & ULTRIB & CHAR & 1 & The upstream left reach's TRIB \\
\hline 25 & $\begin{array}{l}\text { Upstream right reach } \\
\text { SEG }\end{array}$ & URSEG & CHAR & 7 & The upstream right reach's SEG \\
\hline 26 & $\begin{array}{l}\text { Upstream right reach } \\
\text { MI }\end{array}$ & URMI & CHAR & 8 & The upstream right reach's MI \\
\hline 27 & $\begin{array}{l}\text { Upstream right reach } \\
\text { TRIB }\end{array}$ & URTRIB & CHAR & 1 & The upstream right reach's TRIB \\
\hline 28 & $\begin{array}{l}\text { Complement reach } \\
\text { direction }\end{array}$ & CDIR & CHAR & 1 & The inflow direction of complement stream \\
\hline 29 & $\begin{array}{l}\text { Complement reach } \\
\text { SEG }\end{array}$ & CSEG & CHAR & 7 & The complement reach's SEG \\
\hline 30 & Complement reach MI & CMI & CHAR & 8 & The complement reach's MI \\
\hline 31 & $\begin{array}{l}\text { Complement reach } \\
\text { TRIB }\end{array}$ & CTRIB & CHAR & 1 & The complement reach's TRIB \\
\hline
\end{tabular}


Table 5 (Continued). Specifications of the Attribute Table for Line Type Data

\begin{tabular}{|c|c|c|c|c|c|}
\hline No & Attribute & Field name & Type & Length & Definition \\
\hline 32 & Divergence & DIVERGENCE & CHAR & 1 & The presence of divergence reach \\
\hline 33 & Downstream reach SEG & DSSEG & CHAR & 7 & The downstream reach's SEG \\
\hline 34 & Downstream reach MI & DSMI & CHAR & 8 & The downstream reach's MI \\
\hline 35 & Downstream reach TRIB & DSTRIB & CHAR & 1 & The downstream reach's TRIB \\
\hline 36 & Divergent reach SEG & DIVSEG & CHAR & 7 & Divergent reach's SEG \\
\hline 37 & Divergent reach MI & DIVMI & CHAR & 8 & Divergent reach's MI \\
\hline 38 & Divergent reach TRIB & DIVTRIB & CHAR & 1 & Divergent reach's TRIB \\
\hline 39 & Upstream inflow node ID & U_NODEID & CHAR & 16 & The upstream inflow node's ID \\
\hline 40 & $\begin{array}{l}\text { Downstream outflow node } \\
\text { ID }\end{array}$ & D_NODEID & CHAR & 16 & The downstream outflow node's ID \\
\hline 41 & $\begin{array}{l}\text { Upstream inflow point } \\
\text { X-coordinate }\end{array}$ & U_TM_X & NUM & 10.3 & $\begin{array}{l}\text { The X-coordinate of inflow point from upstream (based on Bes- } \\
\text { sel/TM) }\end{array}$ \\
\hline 42 & $\begin{array}{l}\text { Upstream inflow point } \\
\text { Y-coordinate }\end{array}$ & U_TM_Y & NUM & 10.3 & The Y-coordinate of inflow point from upstream \\
\hline 43 & $\begin{array}{l}\text { Downstream outflow point } \\
\text { X-coordinate }\end{array}$ & D_TM_X & NUM & 10.3 & The X-coordinate of outflow point to downstream \\
\hline 44 & $\begin{array}{l}\text { Downstream outflow point } \\
\text { X-coordinate }\end{array}$ & D_TM_Y & NUM & 10.3 & The Y-coordinate of outflow point to downstream \\
\hline 45 & Maximum X-coordinate & MAX_TM_X & NUM & 10.3 & The maximum X-coordinate of reach's extent \\
\hline 46 & Maximum Y-coordinate & MAX_TM_Y & NUM & 10.3 & The maximum Y-coordinate of reach's extent \\
\hline 47 & Minimum X-coordinate & MIN_TM_X & NUM & 10.3 & The minimum X-coordinate of reach's extent \\
\hline 48 & Minimum Y-coordinate & MIN_TM_Y & NUM & 10.3 & The minimum Y-coordinate of reach's extent \\
\hline 49 & $\begin{array}{l}\text { Upstream inflow point } \\
\text { TMDL watershed name }\end{array}$ & U_T_UW_NM & CHAR & 30 & The TMDL's watershed name of inflow point from upstream \\
\hline 50 & $\begin{array}{l}\text { Downstream outflow point } \\
\text { TMDL watershed name }\end{array}$ & D_T_UW_NM & CHAR & 30 & The TMDL's watershed name of outflow point to downstream \\
\hline 51 & $\begin{array}{l}\text { Upstream inflow point } \\
\text { standard watershed code }\end{array}$ & U_K_SW_CD & CHAR & 6 & The standard watershed code of inflow point from upstream \\
\hline 52 & $\begin{array}{l}\text { Downstream outflow point } \\
\text { standard watershed code }\end{array}$ & D_K_SW_CD & CHAR & 6 & The standard watershed code of outflow point to downstream \\
\hline 53 & Update date & UPDATE & DATE & 8 & The updated date \\
\hline
\end{tabular}

stream scale. Furthermore, the skeletonizing method used in this study can be used in various network analysis studies as well as stream information management in the future because of its higher accuracy.

In some streams, such as Munsan Stream, Kyeongan Stream, Banbyeon Stream and Deokcheon River, there was a noticeable difference with the actual length being higher than $10 \%$. This may have been caused by the time difference between the generation time of the river/stream map used for KRF and the Korean River List. The river/stream map was generated in 2005 while the Korean River List dates from 2008. There have been river maintenance work conducted since 2005 that may have caused shape changes of the rivers. This emphasizes the importance of currents in the source data used.

\subsection{Result of Attribute Data Generation}

Attributes were generated for all stream reaches according to the attribute table of the KRF to have 13 attributes for point type data and 53 attributes for line type data (figure 9). Since the KRF attribute contains the topology information of connectivity among the stream reaches, it may also be used for network analysis. This will be useful for searching for upper streams or lower streams that may affect the water quality of relevant drainage systems in a specific stream reach. In addition, the keys that can be used for relational joins with various databases were included in the form of theme attributes. This enables us to provide various environment information data for individual stream reaches upon completing GIS based information systems.

\subsection{Discussion on Applicability in TMDLs implementation}

The Korean TMDLs are legally defined to measure water quality at the end or junction of rivers which are designated by the MOE. The discharge of the pollution sources in the upper 
Table 6. Comparison Results of the Stream Length of the KRF Graphic Data and the Korean River List

\begin{tabular}{|c|c|c|c|c|c|c|c|}
\hline No. & Basin Name & River Name & $\begin{array}{l}\text { Standard } \\
\text { Stream } \\
\text { Code }\end{array}$ & $\begin{array}{l}\text { Length in Korean } \\
\text { River List (A) }[\mathrm{km}]\end{array}$ & $\begin{array}{l}\text { Length in Korean } \\
\text { Reach File (B) }[\mathrm{km}]\end{array}$ & $\begin{array}{l}\text { Length Dif- } \\
\text { ferences } \\
\text { (A-B) }[\mathrm{km}]\end{array}$ & $\begin{array}{l}\text { Absolute Percent- } \\
\text { age Error } \\
|\mathrm{A}-\mathrm{B}| \mathrm{A} * 100[\%]\end{array}$ \\
\hline 1 & \multirow[t]{14}{*}{ Han River Basin } & Han River & 1000010 & 265.4 & 276.7 & -11.3 & 4.3 \\
\hline 2 & & Dal Stream & 1000870 & 15.1 & 15.2 & -0.1 & 0.7 \\
\hline 3 & & Seom River & 1001330 & 55.4 & 56.1 & -0.7 & 1.3 \\
\hline 4 & & $\begin{array}{l}\text { Cheongmi } \\
\text { Stream }\end{array}$ & 1001630 & 25.2 & 25.3 & -0.1 & 0.4 \\
\hline 5 & & Bokha Stream & 1002190 & 19.8 & 19.6 & 0.2 & 1.0 \\
\hline 6 & & Bukhan River & 1002710 & 158.8 & 166.9 & -8.1 & 5.1 \\
\hline 7 & & $\begin{array}{l}\text { Yangguseo } \\
\text { Stream }\end{array}$ & 1002720 & 14.7 & 15.0 & -0.3 & 2.0 \\
\hline 8 & & Soyang River & 1003000 & 77.3 & 74.3 & 3 & 3.9 \\
\hline 9 & & $\begin{array}{l}\text { Kyeongan } \\
\text { Stream }\end{array}$ & 1004290 & 22.5 & 199.9 & 2.6 & 11.6 \\
\hline 10 & & $\begin{array}{l}\text { Jungnang } \\
\text { Stream }\end{array}$ & 1005090 & 20.5 & 21.1 & -0.6 & 2.9 \\
\hline 11 & & $\begin{array}{l}\text { Anyang } \\
\text { Stream }\end{array}$ & 1005380 & 20.7 & 20.7 & 0 & 0 \\
\hline 12 & & $\begin{array}{l}\text { Gongneung } \\
\text { Stream }\end{array}$ & 1005810 & 20.5 & 20.7 & -0.2 & 1.0 \\
\hline 13 & & Imjin River & 1005980 & 91.1 & 90.5 & 0.6 & 0.7 \\
\hline 14 & & $\begin{array}{l}\text { Munsan } \\
\text { Stream }\end{array}$ & 1006760 & 11.6 & 13.8 & -2.2 & 19.0 \\
\hline 15 & \multirow[t]{11}{*}{$\begin{array}{l}\text { Nakdong River } \\
\text { Basin }\end{array}$} & $\begin{array}{l}\text { Nakdong } \\
\text { River }\end{array}$ & 2000010 & 383.0 & 391.1 & -8.1 & 2.1 \\
\hline 16 & & $\begin{array}{l}\text { Banbyeon } \\
\text { Stream }\end{array}$ & 2000250 & 33.7 & 37.2 & -3.5 & 10.4 \\
\hline 17 & & $\begin{array}{l}\text { Naeseong } \\
\text { Stream }\end{array}$ & 2000830 & 27.0 & 26.8 & 0.2 & 0.7 \\
\hline 18 & & Gam Stream & 2001550 & 39.0 & 41.8 & -2.8 & 7.2 \\
\hline 19 & & $\begin{array}{l}\text { Geumho Riv- } \\
\text { er }\end{array}$ & 2001950 & 69.3 & 70.3 & -1.0 & 1.4 \\
\hline 20 & & Hwang River & 2002860 & 78.8 & 83.6 & -4.8 & 6.1 \\
\hline 21 & & Nam River & 2004040 & 144.6 & 143.1 & 1.5 & 1.0 \\
\hline 22 & & $\begin{array}{l}\text { Deokcheon } \\
\text { River }\end{array}$ & 2005160 & 4.2 & 5.0 & -0.8 & 19.0 \\
\hline 23 & & $\begin{array}{l}\text { Haman } \\
\text { Stream }\end{array}$ & 2006110 & 9.6 & 9.9 & -0.3 & 3.1 \\
\hline 24 & & $\begin{array}{l}\text { Milyang Riv- } \\
\text { er }\end{array}$ & 2006950 & 31.5 & 31.3 & 0.2 & 0.6 \\
\hline 25 & & $\begin{array}{l}\text { Yangsan } \\
\text { Stream }\end{array}$ & 2007500 & 10.1 & 10.5 & -0.4 & 4.5 \\
\hline 26 & \multirow{6}{*}{$\begin{array}{l}\text { Geum River } \\
\text { Basin }\end{array}$} & Geum River & 3000010 & 360.7 & 353.1 & 7.6 & 2.1 \\
\hline 27 & & Gap Stream & 3001490 & 33.5 & 33.9 & -0.4 & 1.1 \\
\hline 28 & & $\begin{array}{l}\text { Yudeung } \\
\text { Stream }\end{array}$ & 3001620 & 15.5 & 15.5 & 0.0 & 0.0 \\
\hline 29 & & Miho Stream & 3001810 & 39.1 & 39.6 & -0.5 & 1.2 \\
\hline 30 & & $\begin{array}{l}\text { Nonsan } \\
\text { Stream }\end{array}$ & 3003970 & 21.5 & 23.0 & -1.5 & 7.2 \\
\hline 31 & & $\begin{array}{l}\text { Ganggyeong } \\
\text { Stream }\end{array}$ & 3004230 & 6.4 & 6.7 & -0.3 & 4.5 \\
\hline
\end{tabular}


Table 6 (Continued). Comparison Results of the Stream Length of the KRF Graphic Data and the Korean River List

\begin{tabular}{|c|c|c|c|c|c|c|c|}
\hline No. & Basin Name & River Name & $\begin{array}{l}\text { Standard } \\
\text { Stream } \\
\text { Code }\end{array}$ & $\begin{array}{l}\text { Length in Korean } \\
\text { River List (A) }[\mathrm{km}]\end{array}$ & $\begin{array}{l}\text { Length in Korean } \\
\text { Reach File (B) }[\mathrm{km}]\end{array}$ & $\begin{array}{l}\text { Length Dif- } \\
\text { ferences } \\
\text { (A-B) }[\mathrm{km}]\end{array}$ & $\begin{array}{l}\text { Absolute Percent- } \\
\text { age Error } \\
|\mathrm{A}-\mathrm{B}| / \mathrm{A} * 100[\%]\end{array}$ \\
\hline 32 & \multirow{9}{*}{$\begin{array}{l}\text { Yeongsan/ } \\
\text { Seomjin River } \\
\text { Basin }\end{array}$} & Seomjin River & 4000010 & 173.3 & 173.9 & -0.6 & 0.3 \\
\hline 33 & & Yo Stream & 4001000 & 17.9 & 17.8 & 0.1 & 0.6 \\
\hline 34 & & $\begin{array}{l}\text { Boseong } \\
\text { River }\end{array}$ & 4001390 & 46.8 & 44.4 & 2.4 & 5.1 \\
\hline 35 & & $\begin{array}{l}\text { Yoengsan } \\
\text { River }\end{array}$ & 5000010 & 111.7 & 117.4 & -5.7 & 5.1 \\
\hline 36 & & $\begin{array}{l}\text { Hwangryong } \\
\text { River }\end{array}$ & 5000300 & 9.4 & 9.5 & -0.1 & 1.0 \\
\hline 37 & & Jiseok Stream & 5000600 & 34.0 & 33.8 & 0.2 & 0.6 \\
\hline 38 & & $\begin{array}{l}\text { Gomakwon } \\
\text { Stream }\end{array}$ & 5001220 & 22.4 & 23.9 & -1.5 & 6.8 \\
\hline \multirow[t]{2}{*}{39} & & $\begin{array}{l}\text { Hampyeong } \\
\text { Stream }\end{array}$ & 5001350 & 13.9 & 14.2 & -0.3 & 2.1 \\
\hline & & & & & & MAPE & $3.8 \%$ \\
\hline
\end{tabular}

watershed that affect the end or junction of rivers must be controlled when the concentration of Biochemical Oxygen Demand (BOD) or Total Phosphorus (T-P) exceeds the preset permissible level (MOE, 2004). Under these parameters, it is difficult to easily search for stream reaches that are directly affected by individual pollution sources without the KRF. In the past, visual assessment using a paper map was the only way to identify pollution sources. The limitation of that system is that it does not minimize the expansion and diffusion of water pollution through prompt action. Furthermore, it is impossible to clearly define stream reaches that are affected by individual pollution sources and this can lead to legal disputes over the responsibility among municipalities.

We expect that the KRF will be used as an efficient scientific tool to provide a solution for the problem mentioned above. The KRF's unique identifiers can be used as the spatial addresses on stream networks (Lee et al., 2014). Once a unique identifier of the relevant stream reach adjacent to the discharge site of individual pollution sources is identified, it can be linked to individual records of existing pollution source databases. This will provide a list of pollution sources linked to the target stream reach within a short period of time, thereby enhancing the capabilities of mitigation strategies. The KRF also enables a network analysis for path finding, since it contains topology information of stream reaches connected upstream. It is possible to search for every relevant pollution source by exploring stream reaches in the upstream direction through a network analysis. This will support an analysis of discharge records of the sought pollution sources to find a cause and establish BMPs.

Figure 10a displays an example of pollution source information linkage and search using the KRF. The region shown in this figure is Kyeongan Stream's watershed, one of the twenty-four watersheds in the Han River basin. As shown on the left side, there are nine sewage treatment plants and ten water quality measurement sites. In this case, on the assumption that the concentration of BOD at the fifth water quality measurement site from the bottom exceeds the permissible level, the list of pollution sources affecting the site can be searched for through network analysis and database search using the KRF, as shown in Figure 10.b. First, it is necessary to choose a water quality measurement site and check a KRF Node ID for the site. In the example, the KRF Node ID value of the site is '1024290 11.95600'. The next step is to search for stream reaches adjacent to the node by finding the records that include the KRF Node ID value of the site at the $<$ D_NODE ID $>$ field of the attributes table in the KRF's line. Two records which have <RCHLINID> as '1024290 11.956001 ' and '102429 11.95600 2' were found.

Next it is necessary to repeatedly search for stream reaches connected to the upstream area from those reaches. The unique identifier of the stream reaches in the left upstream direction '1024290 22.80969 2' can be created by combining the attributes in the fields of $<$ ULSEG $>$, $<$ ULMI $>$ and $<$ ULTRIB $>$ of the first record. Then, the newly created unique identifier can be used to search for the record that has the same value in the field of $<$ RCHLINEID $>$. As shown in Figure 10b, the third record with an attribute of $<$ RCHLINEID $>$ as ' 1024290 22.80969 2'can be found. Searching for stream reaches connected to the upstream area must be repeated until there are no more stream reaches connected to the upstream area. Likewise, the stream reaches in the right upstream direction must be searched for repeatedly using the attributes in the fields of $<$ URSEG $>$, <URMI $>$ and $<$ URTRIB $>$.

Finally, the list of stream reaches extracted from the repeated search process can be used to find pollution sources. In this example, forty-six stream reaches and four sewage treatment plants relevant to them were found, as shown in Figure $10 \mathrm{~b}$.

The search results can also be used for mapping in GIS 
Han River Basin

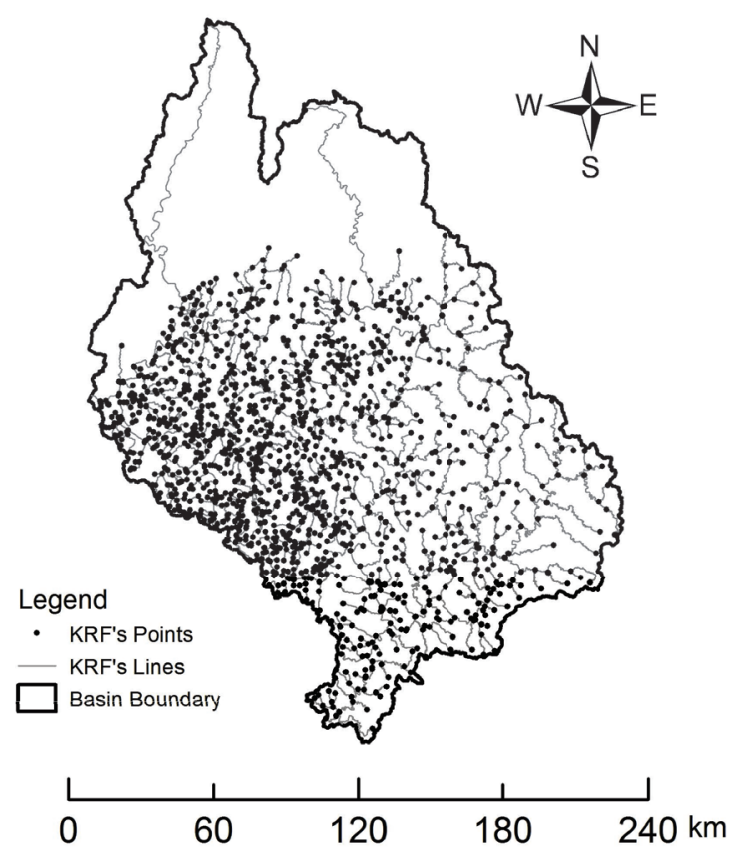

Nakdong River Basin

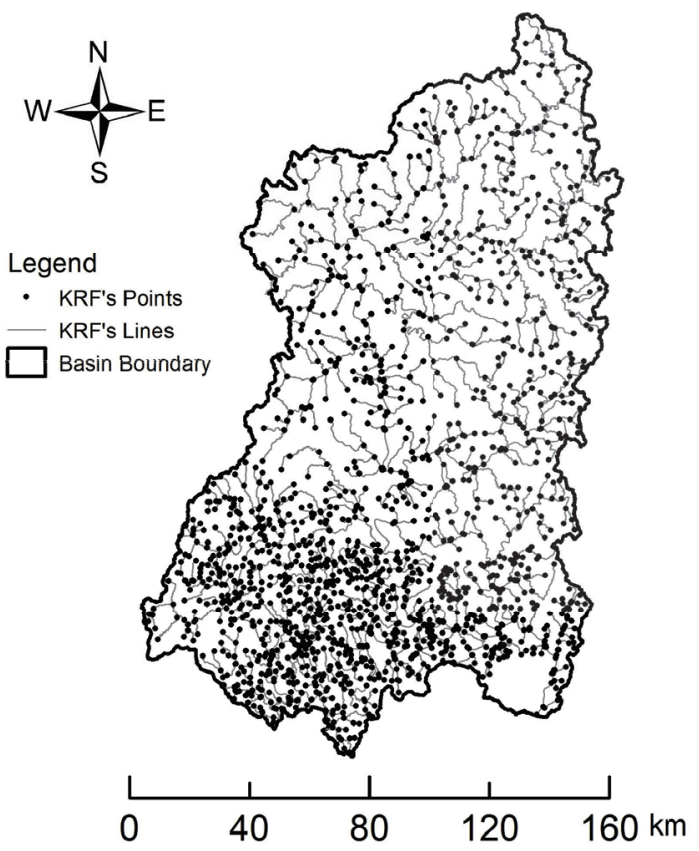

Geum River Basin

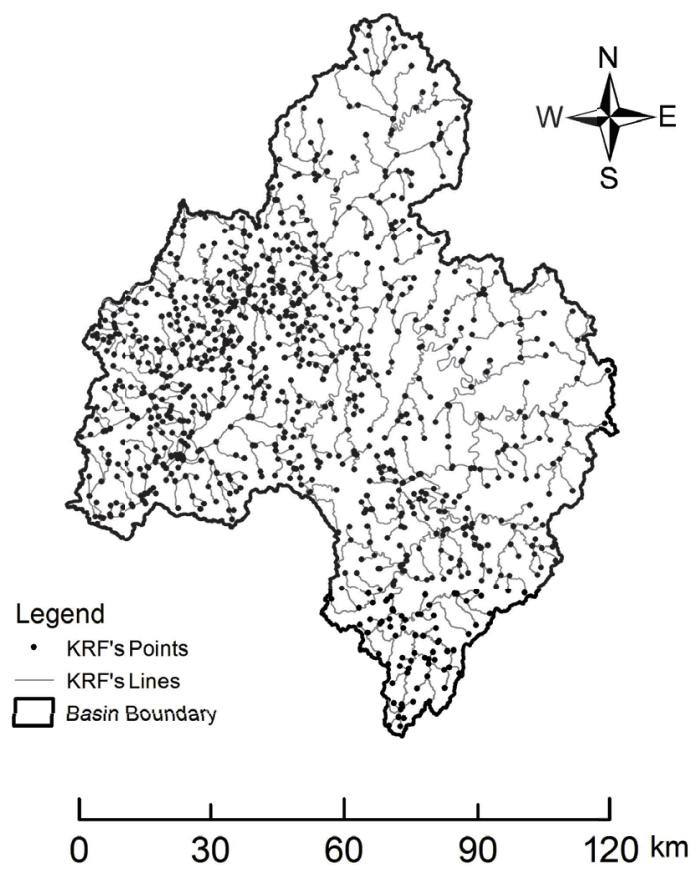

\section{Yeongsan/Seomjin River Basin}

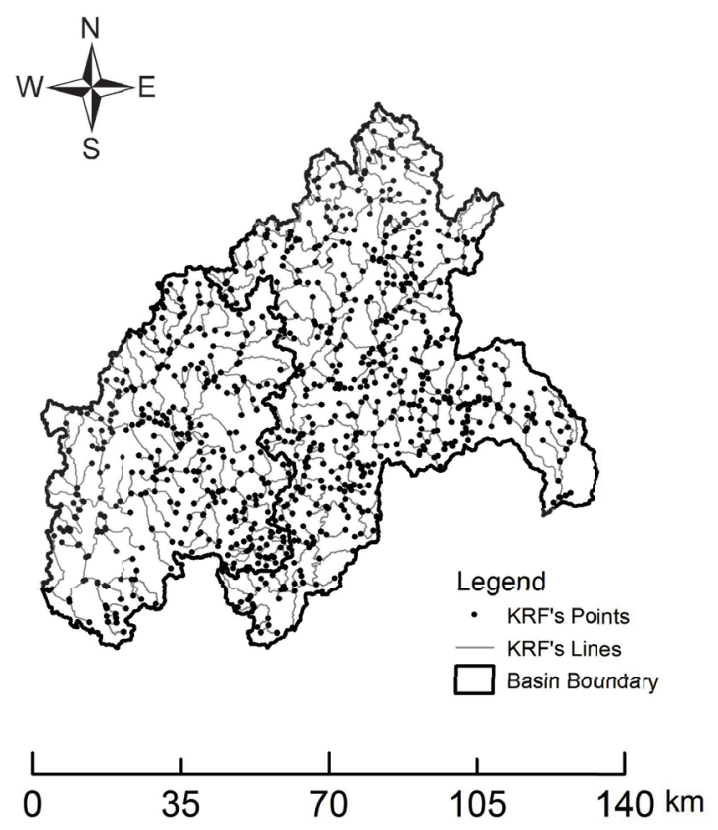

Figure 7. Results of generated KRF's graphic data of four major river basins. 


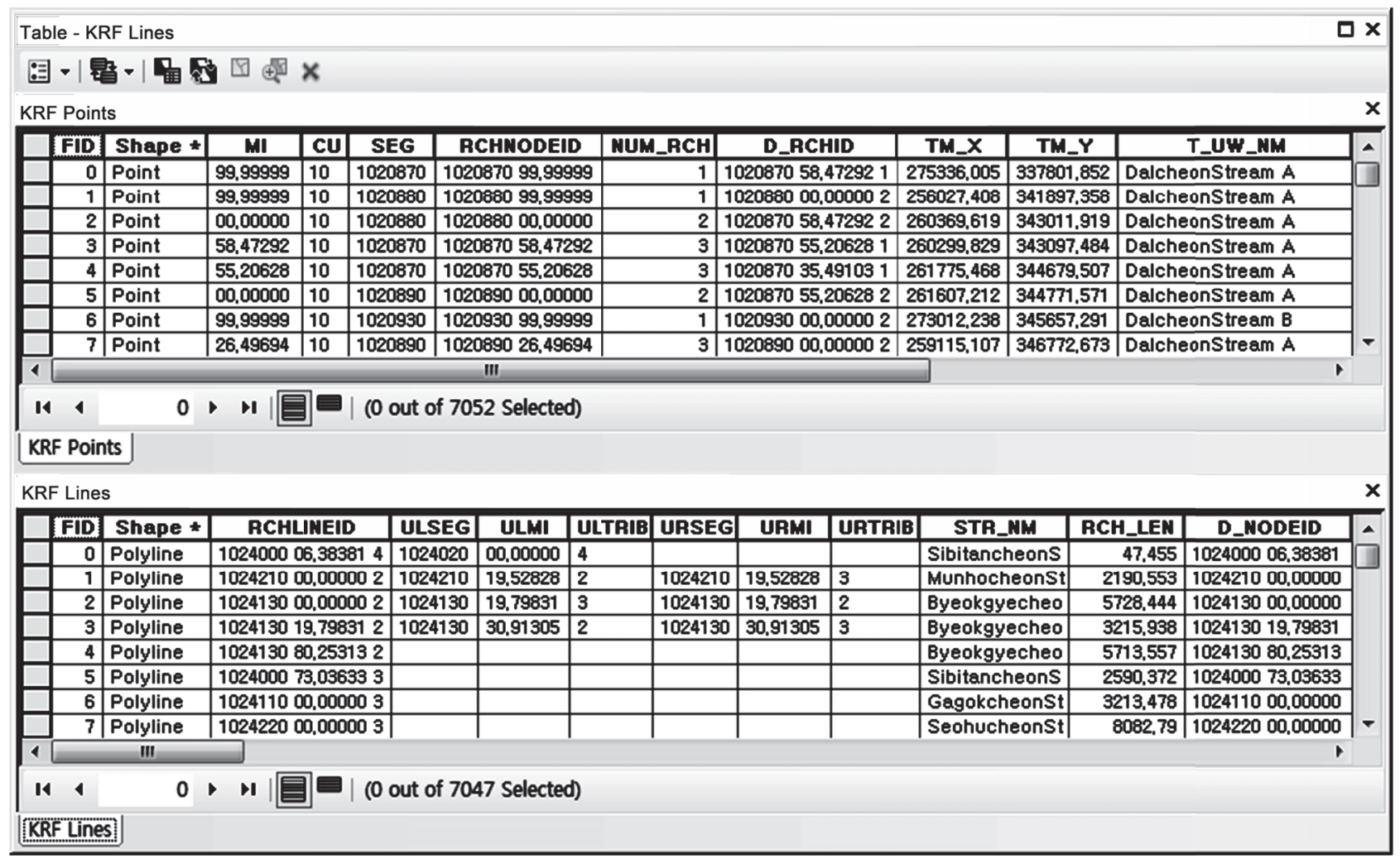

Figure 9. Results of the KRF's attribute table.

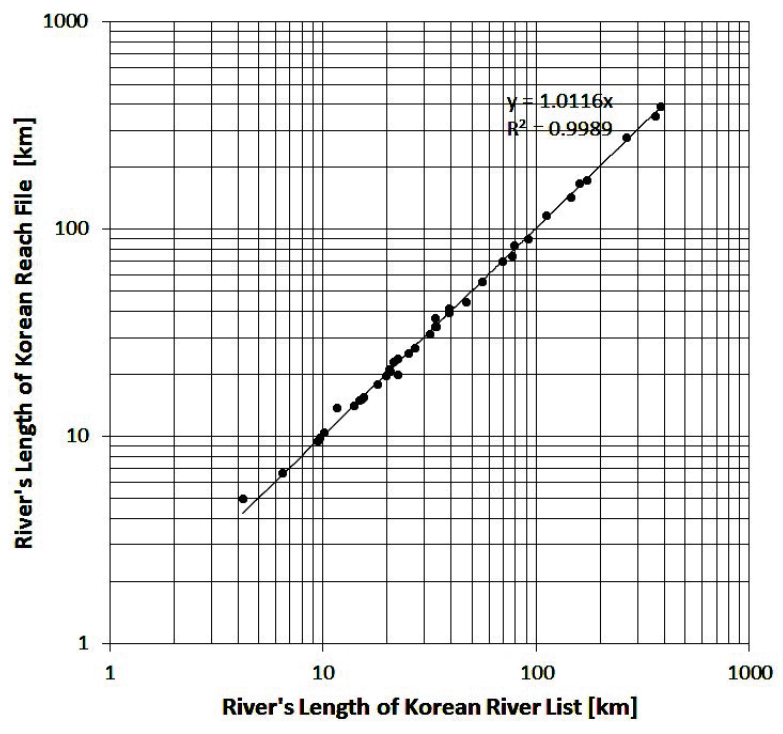

Figure 8. Scatter plot for comparison of national rivers' lengths.

environment, as shown in the right side of Figure 10a. This can be a significant contribution to establish more realistic BMPs considering spatial distribution and correlation among spatially distributed relevant factors. It is also possible to easily predict and identify stream sections that might be influenced by water pollutants in the future by applying this method in the downstream direction. In particular, this can be applied in a similar way by entering KRF's unique identifiers in various databases related to facilities such as intake stations, purification plants and leisure facilities (swimming pools, fishing sites, etc.). This application will support more efficient decision-making to analyze water pollution scenarios.

The scientific assessment of discharge permission and the management of diverse pollution sources through prediction of water quality changes in TMDLs require a GIS based water quality simulation and assessment support system such as the U.S. EPA's BASINS (USEPA, 2001). Such a system will support diverse use of models related to water quality with the linkage of the KRF attributes. The KRF attributes contain basic information required for creating a model schematic diagram like the length of stream reaches (in the field of $\langle$ RCH_LEN $>$ ), the Boolean variable of uppermost stream reaches (in the field of $<$ S_FLAG $>$ ), the Boolean variable of lowest stream reaches (in the field of $<$ T_FLAG $>$ ), the Boolean variable of stream reach connection (in the field of $\langle$ R_FLAG $>$ ), and so on. Therefore, the KRF can be used effectively in preprocessing topographical data and creating model input data for water quality simulation (Park et al., 2013) once the GIS based modeling system has been developed.

\section{Conclusions}

In this study, the GIS based KRF was generated for the four major river basins in South Korea as the stream network data to support TMDLs implementation. The method's effec- 


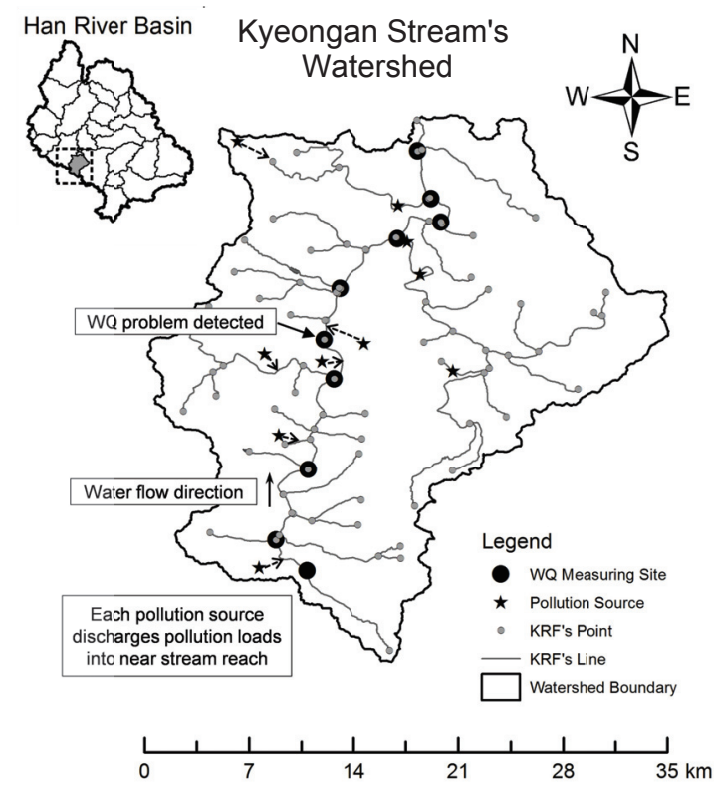

Water Pollution Sources Influencing Selected Measuring Site

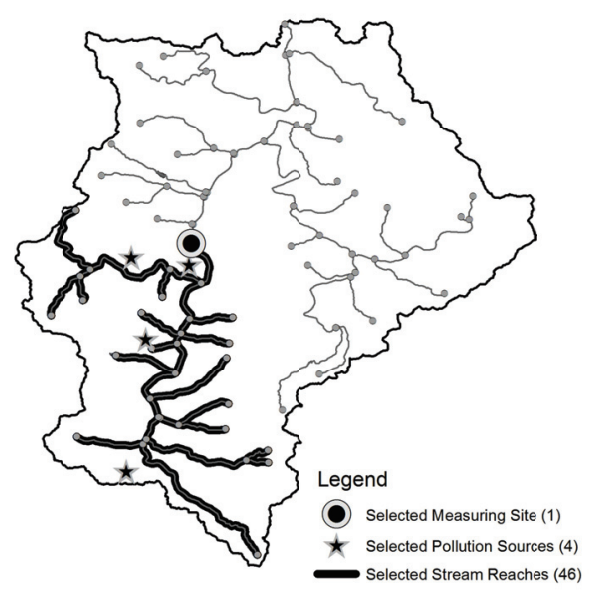

(a) Application to search pollution sources for TMDLs (Left: a scenario, Right: a search result)

WQ Measuring Site Attribute Table

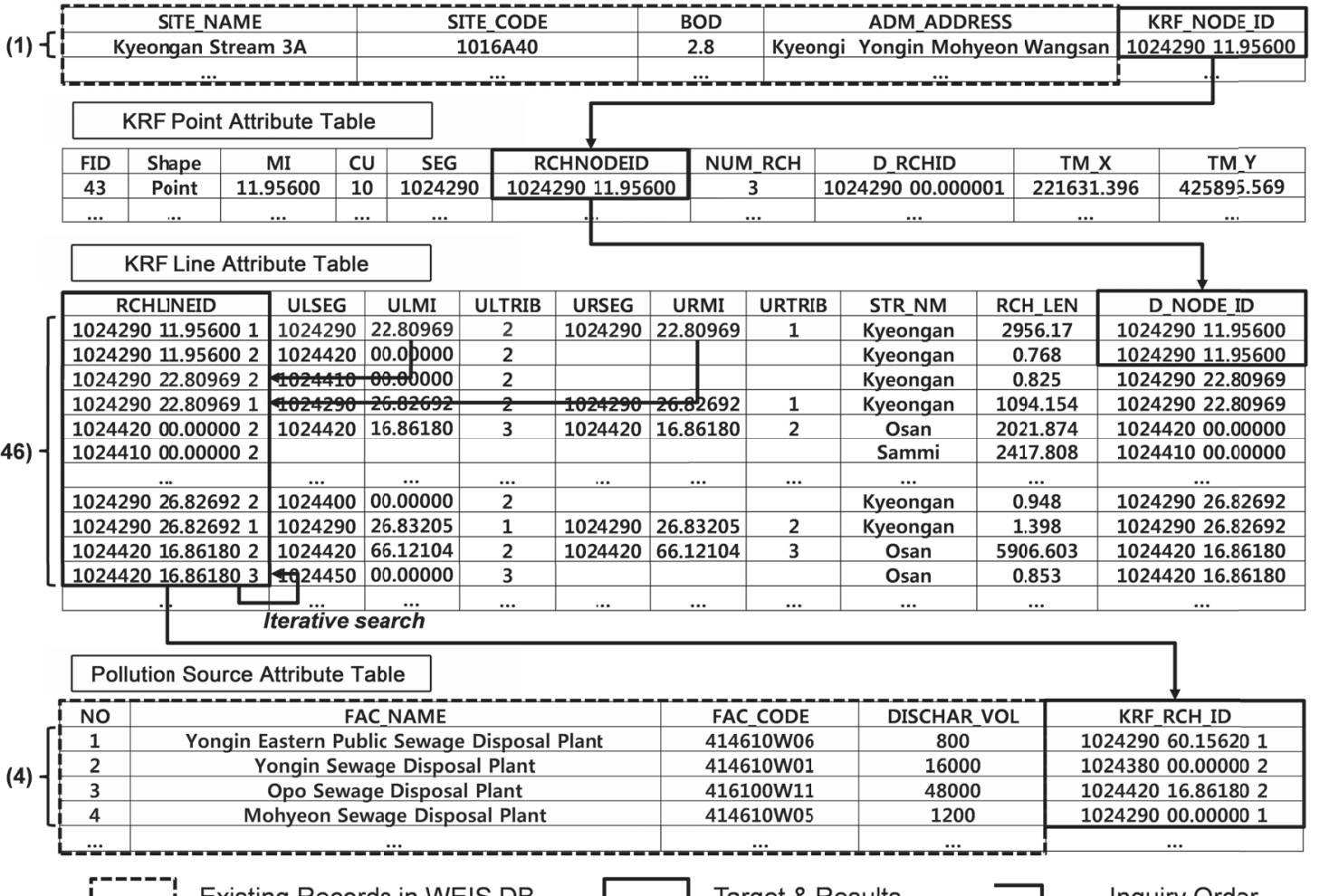

Existing Records in WEIS DB $\square$ Target \& Results $\longrightarrow$ Inquiry Order

(b) Search process of the pollution source data using the KRF

Figure 10. Application example of the KRF for TMDLs. 
tiveness and accuracy were evaluated. In addition, future application and utilization plans for the KRF were discussed.

The previous studies of the U.S. and South Korea were investigated to define an appropriate methodology to generate the KRF. To produce line type graphic data required for the generation of network spatial data, the skeletonizing method connecting center points from maximum inscribed circles was applied. Adopting the skeletonizing method and post-processing, the stream flow line was delineated from a vector type river/stream map. In addition, with the application of the stream reach split standard defined in this study, the line type graphic data of a stream reach unit can be produced. The point type graphic data were produced through the screen digitizing at the start and end points of individual stream reaches. The uni- que identifier was developed using Korean standard stream code and all stream reaches and nodes could be identified. Fi- nally, themes, location and topology attributes were entered for all the stream reaches according to the attribute design.

A total of 7,047 stream reaches were delineated for 2,402 rivers and streams, and their total length was $21,163.27 \mathrm{~km}$. As the result of comparing with Korean River List--the actual surveyed data of major national rivers--the MAPE was found to be about 3.8\%; an acceptable level of accuracy for the proposed method. The KRF and relevant network data can surely contribute to enhancing the network analysis in TMDLs implementation. The unique identifier and several theme attributes can be utilized for data connection with various existing stream databases of environment information. Furthermore, the topology attributes could be used for more effective network analysis. The study results also suggest that further research is needed to validate the efficiency and usefulness of the KRF with more efforts to develop various application systems to utilize the KRF in TMDLs work.

Acknowledgments. This research was supported by INHA UNIVERSITY Research Grant.

\section{References}

Cooter, W., Rineer, J., and Bergenroth, B. (2010). A nationally consistent NHDPlus framework for identifying interstate waters: Implications for integrated assessments and interjurisdictional TMDLs. Environ. Manage., 46(3), 510-524. http://dx.doi.org/10.1007/s0026 7-010-9526-y

Dewald, T., and Roth, K. (1997). The national hydrography dataset Integrating the US EPA reach file and USGS DLG. Proc. of 1997 ESRI International User Conference. Environmental Systems Research Institute, Redlands, CA.

Huang, G.H., and Chang, N.B. (2003). Perspectives of environmental informatics and systems analysis. J. Environ. Inf., 1(1), 1-6. http:// dx.doi.org/10.3808/jei.200300001

Huang, G.H., Liu, L., Chakma, A., Wang, X.H., and Yin, Y.Y. (1999). A hybrid GIS-supported watershed modeling system. Hydrol. Sci. J., 44(4), 597-610. http://dx.doi.org/10.1080/02626669909492255

Ierardi, M.C., Alexander, R.B., Schwarz, G.E., and Smith, R.A. (2004). SPARROW-WEB: A graphical interactive system for displaying reach-level water-resource information for rivers of the conterminous United States, Proc. AWRA Spring Specialty Con- ference, Geographic Information Systems and Water Resources III.

Jensen, S.K., and Domingue, J.O. (1988). Extracting topographic structure from digital elevation data for geographic information system analysis. Photogramm. Eng. Remote Sensing., 54(11), 15931600.

Karimipour, F., Delavar, M.R., and Kinaie, M. (2005). Water quality management using GIS data mining. J. Environ. Inf., 5(2), 61-72. http://dx.doi.org/10.3808/jei.200500047

Kim, H., Nam, K., and Lee, S. (2004a). A study on using networkGIS for the integrated management of urban stream. J. Korea Plan. Assoc., 39(2), 295-307.

Kim, K. (2010). Spatial Analysis, Munundang Press.

Kim, K., Choi, Y., and Kim, J. (2004b). A study on the construction of the framework spatial DB for developing watershed management system based on river network. J. Korea Assoc. Geog. Info. Studies., 7(2), 87-96.

Kong, D. (2005). Present status and perspective of Korean TMDLs. Mag. Korea Water Resour. Assoc., 38(3), 14-22.

Kwon, M., Kim, K., Lee, C., and Park, Y. (2012). Design of GIS based Korean reach file supporting water quality modeling. $J$. Korea Water Resour. Assoc., 45(1), 1-13. http://dx.doi.org/10.3741/JK WRA.2012.45.1.1

Lee, C., Kim, K., Park, Y., and Lee, H. (2014). Construction schemes of GIS-based integrated water environment information management system linked with Korean reach file. J. Korea. Society Water Environ., 30(2), 226-241. http://dx.doi.org/10.15681/KSWE.2014. 30.2.226

Lee, C., Kim, K., Park, Y., and Lee, H. (2013). A study to improve the spatial data design of Korean reach file to support TMDL works. J. Korea Water Resour. Assoc., 46(4), 345-459. http://dx. doi.org/10.3741/JKWRA.2013.46.4.345

Lee, C., Park, Y., and Kim, K. (2009). A study on stream centerline extraction algorithm for vector data using skeletonizing technique, Proc. of 2009 Joint conference of Korea Spatial Information System Society, the Korean society for Geospatial Information System, Geographic Information System Association, Korea Spatial Information System Society, S. Korea.

Lovejoy, S.B. (1997). Watershed management for water quality protection: Are GIS and simulation models the answer?. J. Soil Water Conserv., 52, 103-110.

Luk, G.K., Nie, J., and Li, J. (2004). Enhancement of fish bioaccumulation models with environmental geoinformatics. J. Environ. Inf., 4(1), 1-10. http://dx.doi.org/10.3808/jei.200400032

Maidment, D.R. (2002). Arc Hydro-GIS for Water Resources, Environmental Systems Research Institute Press.

Maidment, D.R., and Djokic, D. (2000). Hydrologic and Hydraulic Modeling Support with GIS, Environmental Systems Research Institute, Redlands, CA.

MLTM (2013). Water Management Information System (South Korea). http://www.wamis.go.kr/ (accessed Nov 6, 2013).

MLTML (2008). Korean River List, Han River Flood Control Office, Ministry of Land, Transport and Maritime Affairs, S. Korea.

MOCT (2004). Standard of Water Management Information, Ministry of Construction \& Transportation, S. Korea.

MOE (2004). Task Manual of Total Maximum Daily Loads, Ministry of Environment, S. Korea.

NIER (2011). User's Manual of Water Environment Information System, National Institute of Environment Research, S. Korea.

Park, Y., Kim, K., Lee, C., and Lee, S. (2013). Developing algorithm of automated generating schematic diagram for one-dimensional water quality model using Korean reach file. J. Korea Spatial Info. Society, 21(6), 91-98. http://dx.doi.org/10.12672/ksis.2013.21.6.091

Park, Y., Kim, K., and Lee, C. (2010). Study on GIS based automatic delineation method of accurate stream centerline for water quality 
modeling. J. Korea Spatial Info. Society, 18 (4), 13-22.

Ries, K.G., Guthrie, J.D., Rea, A.H., Steeves, P.A., and Stewart, D.W. (2010). Use of the StreamStats Web application for TMDL analysis, Proc. of the TMDL2010: Watershed Management to Improve Water Quality, Hyatt Regency Baltimore on the Inner Harbor, Baltimore, Maryland, USA, pp. 14-17, 2010.

Saunders, W. (1999). Preparation of DEMs for use in environmental modeling analysis, Proc. of the 1999 Environmental Systems Research Institute Users Conference, Environmental Systems Research Institute, Redlands, CA.

Tarboton, D.G., Bras, R.L., and Rodriguez-Iturbe, I. (1991). On the extration of channel networks from digital elevation data, Proc. of the Hydrological, vol. 5, pp. 81-100, http://dx.doi.org/10.1002/hyp. 3360050107

USEPA (2013a). Watershed Assessment, Tracking \& Environmental Results, United States, http://water.epa.gov/scitech/datait/tools/wa ters/docs/basic_information.cfm/ (accessed Nov 6, 2013).

USEPA (2013b). National Hydrography Dataset Model, United States, http://water.epa.gov/scitech/datait/tools/waters/docs/nhd model.cf $\mathrm{m} /$ (accessed Nov 6, 2013).

USEPA (2003a). DC Portion of the Rock Creek Watershed Total Maximum Daily Load Calculation, Environmental Protection Agency, Washington, U.S..

USEPA (2003b). Total Maximum Daily Load For Nutrients and Dissolved Oxygen for the Appoquinimink River, Environmental Protection Agency, Washington, U.S..

USEPA (2001). Better Assessment Science Integrating point and Nonpoint Sources (BASINS version 3.0) - User's Manual, Environmental Protection Agency, Washington, U.S..

USEPA (1994a). History of U.S. EPA's River Reach File: A National Hydrographic Database Available for ARC/INFO Application, Environmental Protection Agency, Washington, U.S..

USEPA (1994b). EPA Reach File Version 3.0 Alpha Release (RF3Alpha) Technical Reference, Environmental Protection Agency, Washington, U.S.. 